\title{
Acute effects of endocannabinoid anandamide and CB1 receptor antagonist, AM251 in the regulation of thyrotropin secretion
}

\author{
Marco Aurélio Liberato Costa da Veiga ${ }^{1}$, Flávia Fonseca Bloise ${ }^{1}$, Ricardo Henrique Costa-e-Sousa ${ }^{1}$, \\ Luana Lopes Souza ${ }^{1}$, Norma Aparecida dos Santos Almeida ${ }^{1}$, Karen Jesus Oliveira ${ }^{1,2}$ \\ and Carmen Cabanelas Pazos-Moura, \\ ${ }^{1}$ Laboratório de Endocrinologia Molecular, Instituto de Biofísica Carlos Chagas Filho, Universidade Federal do Rio de Janeiro, Rio de Janeiro 21949-900, Brazil \\ ${ }^{2}$ Departamento de Fisiologia e Farmacologia, Universidade Federal Fluminense, Rio de Janeiro 23070-200, Brazil \\ (Correspondence should be addressed to C C Pazos-Moura; Email: cpazosm@biof.ufrj.br)
}

\begin{abstract}
We examined the acute effects of endocannabinoid, anandamide, and of synthetic cannabinoid receptor antagonist, AM251[N-(piperidin-1-yl)-1-(2,4-dichlorophenyl)-5-(4chlorophenyl)-4-methyl-1H-pyrazole-3-carboxamide], on TSH, thyroxine $\left(\mathrm{T}_{4}\right)$, and triiodothyronine $\left(\mathrm{T}_{3}\right)$ secretions. Euthyroid male rats showed a 42\% decrease in serum TSH, 2 h after a single i.p. injection of $0 \cdot 02$, but not $0.2 \mathrm{mg} / \mathrm{kg}$ body weight $(\mathrm{BW})$, anandamide, accompanied by a $39 \%$ reduction in serum $\mathrm{T}_{4}$, without alteration in serum $\mathrm{T}_{3}$. At 0.5 and $1 \mathrm{~h}$, these serum hormones showed no significant change. Hypothyroid rats showed a $35 \%$ reduction in serum TSH $(P<0 \cdot 01), 2 \mathrm{~h}$ after anandamide injection, which had no effect on hyperthyroid rats. In both thyroid states, no modification of serum thyroid hormones was observed. Intraperitoneal injection of 0.17 or $1.7 \mathrm{mg} / \mathrm{kg} \mathrm{BW}$ AM251 in euthyroid rats caused, $1.5 \mathrm{~h}$ later, $1 \cdot 7$-fold or $4 \cdot 3$-fold increase in serum TSH respectively, without changing thyroid
\end{abstract}

hormones. Stimulatory effect of $0 \cdot 17 \mathrm{mg} / \mathrm{kg} \mathrm{BW}$ AM251 and inhibitory effect of anandamide was abolished in the group injected with AM251 followed by an anandamide injection, $30 \mathrm{~min}$ later. Intracerebroventricular injection of $20 \mathrm{ng}$ (but not $200 \mathrm{ng}$ ) anandamide induced a decrease in serum TSH at $60 \mathrm{~min}$ after injection, which tended to disappear at $120 \mathrm{~min}$. Anterior pituitary explants presented significant reduction in $\mathrm{TSH}$ release in the presence of $10^{-7} \mathrm{M}$ anandamide in incubation medium, which was blocked by $10^{-7} \mathrm{M}$ AM251. In conclusion, anandamide has the ability to acutely inhibit $\mathrm{TSH}$ release in eu- and hypothyroid rats, acting at the hypothalamus-pituitary axis. Since, in addition, the cannabinoid receptor antagonist AM251 increased TSH release, we suggest that endocannabinoid system has a role as negative regulator of TSH secretion.

Journal of Endocrinology (2008) 199, 235-242

\section{Introduction}

The active principle isolated from Cannabis sativa, $\Delta 9$ tetrahydrocannabinol $(\Delta 9$-THC), has many well-known pharmacological properties. The actions of this phytocannabinoid are mediated by two subtypes of G-protein coupled receptors, CB1 (also known as CNR1) and CB2 (also known as CNR2) (Devane et al. 1988, Matsuda et al. 1990, Munro et al. 1993). CB1 is abundant in the central nervous system, and it is also present in the peripheral nervous system and in several peripheral organs (Tsou et al. 1998). By contrast, CB2 receptor expression in the brain is very low and it is located mostly in immune cells (Klein 2005). Endogenous ligands of cannabinoid receptors were identified and named endocannabinoids (Di Marzo \& Fontana 1995). The main endocannabinoids are arachidonoyl ethanolamide (anandamide) and 2-arachidonoyl glycerol, derivates of arachidonic acid, which are produced by the cleavage of membrane lipid precursors (Di Marzo et al. 2004). Endocannabinoids and their receptors together with enzymes for ligand biosynthesis and inactivation comprise the endocannabinoid system (Di Marzo et al. 2004). This system participates in several physiological processes, such as nociceptive transmission, motor activity, learning and memory process, emotional responses, as well as thermoregulation and appetite regulation (Di Marzo et al. 2004, Foster-Schubert \& Cummings 2006).

In addition, it has been shown that endocannabinoids have a role in the control of the neuroendocrine system. Anandamide modulates prolactin (PRL) and luteinizing hormone (LH) CGR secretions in a sex steroid-dependent manner. In male rats and female ovariectomized rats, anandamide had the ability to suppress PRL and LH release (Wenger et al. 1995, Scorticati et al. 2003, 2004), while in ovariectomized estrogenprimed rats, it stimulated PRL and LH release (Scorticati et al. 2003, 2004). Regarding growth hormone secretion, one report found that $\Delta 9$-THC administration increased while anandamide decreased the hormone serum concentrations (Wenger et al. 1995). There are also reports that anandamide, 
centrally injected in rats, was able to increase the secretion of adrenocorticotropin hormone (Weidenfeld et al. 1994).

Earlier reports have demonstrated the ability of a single injection of the phytocannabinoid $\Delta 9-\mathrm{THC}$ to reduce serum concentrations of TSH and thyroid hormones (Hillard et al. 1984). Another study (Lomax et al. 1970) suggested that the reduction in thyrotropic axis would be consequent to hypothalamic action of $\Delta 9$-THC, resulting in decreased thyrotropin-releasing hormone (TRH) release, although so far, direct evidence is lacking. More recently, it was shown that the synthetic cannabinoid receptor agonist WIN 55212-2 also reduced serum triiodothyronine $\left(\mathrm{T}_{3}\right)$ and thyroxine $\left(\mathrm{T}_{4}\right)$, but no alteration was observed on serum TSH (Porcella et al. 2002). Therefore, in the present paper, in order to contribute further insights into the role of the endogenous cannabinoid system on thyrotropic axis function, we investigated the acute effect of anandamide on TSH secretion in vivo and in vitro. We also analyzed the acute effect of a CB1 receptor antagonist, AM251, since CB1 receptors are present at hypothalamus, pituitary, and thyroid glands (Fernandez-Ruiz et al. 1997, Wenger et al. 1999, Porcella et al. 2002, Scorticati et al. 2004).

\section{Materials and Methods}

\section{Animals}

Adult male Wistar rats, 250-300 g body weight (BW), were kept under a $12 \mathrm{~h}$ light: $12 \mathrm{~h}$ darkness cycle (light onset at $0700 \mathrm{~h}$ ) at $24 \pm 1^{\circ} \mathrm{C}$; a standard diet and tap water were available ad libitum. All experimental protocols were approved by our institutional animal care committee Comissão de Avaliação de Utilização de Animais em Pesquisa (CAUAP) and are in accordance with the FRAME's guidelines. Experiments were performed with eu-, hypo-, and hyperthyroid rats. Hypothyroidism was induced by treatment with $0.03 \%$ methimazole (Sigma) in the drinking water for 21 days. Hyperthyroidism was induced by s.c. daily single injection of $\mathrm{T}_{4}$ (L-Thyroxine Sigma), $10 \mu \mathrm{g} / 100 \mathrm{~g} \mathrm{BW}$ for 6 days.

\section{In vivo experiments}

Systemic administration of anandamide or AM251, a selective CB1 receptor antagonist Euthyroid animals were divided into four groups that received a single i.p. injection of vehicle (propylene glycol:ethanol:saline 1:1:2 control) or $0.02 \mathrm{mg} / \mathrm{kg} \mathrm{BW}$ anandamide (Tocris Cookson Inc., Ellisville, MO, USA) and killed by decapitation $0 \cdot 5,1$, or $2 \mathrm{~h}$ after the injection. Control group was killed at a time between 1 and $2 \mathrm{~h}$. Other group of euthyroid rats received a single i.p. administration of vehicle or $0.2 \mathrm{mg} / \mathrm{kg} \mathrm{BW}$ anandamide and killed $2 \mathrm{~h}$ later. Drug administration protocol was based on that employed by Wenger et al. (1997) who demonstrated that $0.02 \mathrm{mg} / \mathrm{kg} \mathrm{BW}$ anandamide stimulated the secretion of adrenocorticotropic hormone (ACTH) and corticosterone in rats.
Hypo- and hyperthyroid animals were divided into two groups that received a single i.p. injection of vehicle (control) or $0.02 \mathrm{mg} / \mathrm{kg} \mathrm{BW}$ anandamide, and killed $2 \mathrm{~h}$ later. The time was chosen based on the results observed on euthyroid animals.

In order to evaluate the response of the thyroid axis to selective CB1 receptor antagonist/inverse agonist, AM251, euthyroid animals were injected i.p. with vehicle ( $3 \% \mathrm{DMSO})$, $0.17 \mathrm{mg} / \mathrm{kg}$ or $1.7 \mathrm{mg} / \mathrm{kg} \mathrm{BW}$ of AM251 [ $\mathrm{N}$-(piperidin-1yl)-1-(2,4-dichlorophenyl)-5-(4-chlorophenyl)-4-methyl$1 H$-pyrazole-3-carboxamide] (Tocris Cookson Inc.), and killed $1.5 \mathrm{~h}$ later. AM251 dose was chosen based on previous reports on behavior studies that had injected rats with the drug intraperitoneally (Chambers et al. 2004, McLaughlin et al. 2005, Xi et al. 2006).

In order to investigate the involvement of endocannabinoid receptors on the effect of anandamide on the thyrotropic axis, $0.17 \mathrm{mg} / \mathrm{kg}$ BW AM251 was injected $30 \mathrm{~min}$ before the administration of $0.02 \mathrm{mg} / \mathrm{kg}$ anandamide in euthyroid rats, and compared with groups treated with $0.02 \mathrm{mg} / \mathrm{kg}$ anandamide alone or $0.17 \mathrm{mg} / \mathrm{kg}$ BW AM251 alone. To serve as a control group, half of the animals were injected with AM251 vehicle and other half with anandamide vehicle, and since data of these two groups did not differ, they were pooled and presented together. Animals were killed $2 \mathrm{~h}$ after anandamide injection.

In all experiments, animals were killed by decapitation and serum was obtained from trunk blood to measure TSH and total $T_{4}$ and $T_{3}$ concentrations. Experiments were performed until $1100 \mathrm{~h}$, in order to avoid circadian fluctuations interfering with results.

\section{Central administration of anandamide}

Rats underwent third ventricular cannulation (i.c.v.) 7 days before the experiment. A stainless steel guide cannula $(0 \cdot 6 \mathrm{~mm}$ o.d.) for microinjection was implanted $0.5 \mathrm{~mm}$ posterior to bregma and $8 \cdot 0-8 \cdot 5 \mathrm{~mm}$ ventral to the skull, as reported before (Antunes-Rodrigues \& McCann 1970, Rettori et al. 1992), under ketamine plus xylazine anesthesia. Verification of correct cannula placement was made by the observation of fluid-filled column (attached to guide cannula) displacement. The day before the experiment, a jugular catheter was implanted, under the same anesthetic protocol described above. Briefly, the jugular vein was isolated by blunt dissection and a catheter made of silastic tubing was introduced about $2 \cdot 2 \mathrm{~mm}$ down. The free end of the catheter was passed under the skin and externalized between the scapulae. The catheter was flushed with heparin saline $(50 \mathrm{U} / \mathrm{ml})$. The next morning, extension tubing was attached to the jugular catheter and animals were left undisturbed for half an hour, then a basal heparinized blood sample was collected, followed by the i.c.v. injection of a solution of 20 or $200 \mathrm{ng}$ anandamide in $2 \mu \mathrm{l}$ or an equal volume of vehicle (Trocrisolve, Tocris Cookson Inc). Blood samples were collected 30, 60, and $120 \mathrm{~min}$ after microinjection. After each sample collection, volume replacement was conducted with sterile saline. 
In vitro experiments: pituitary explants

The in vitro protocol was performed as described previously (Rettori et al. 1989, 1992, Pazos-Moura et al. 1996, Ortiga-Carvalho et al. 2002). Euthyroid animals were killed by decapitation and their anterior pituitaries were quickly dissected. Each hemi-pituitary was immediately transferred to a flask containing $1 \mathrm{ml}$ Krebs-Ringer bicarbonate medium $(\mathrm{pH} 7 \cdot 4)$ at $37^{\circ} \mathrm{C}$ in an atmosphere of $95 \% \mathrm{O}_{2}: 5 \% \mathrm{CO}_{2}$ in a Dubnoff metabolic shaker. After a 30-min preincubation period, medium was changed and glands were incubated in the absence or presence of tested drugs. In the first experiment, glands were incubated with $10^{-11}, 10^{-9}$, or $10^{-7} \mathrm{M}$ anandamide in Tocrisolve (Tocris Cookson Inc). In the second experiment, glands were incubated with anandamide or AM251 or both drugs at the same molarity $\left(10^{-7} \mathrm{M}\right)$. At the end of 2-h incubation an aliquot was removed, and kept at $-20{ }^{\circ} \mathrm{C}$ until assayed for TSH measurement.

\section{Hormone measurements}

TSH concentrations in serum and in incubation medium were measured by specific RIA, employing reagents supplied by National Hormone and Peptide Program (Torrance, CA, USA), as previously described (Chard 1987, Ortiga-Carvalho et al. 1996), and it was expressed in terms of the reference preparation (RP3). The assay is highly specific for rat TSH and no significant cross-reactivity is reported by the supplier. Minimum assay detection value was $0 \cdot 18 \mathrm{ng} / \mathrm{ml}$ and withinassay variation was less than $8 \%$ in all assays. Total serum $\mathrm{T}_{4}$ and $\mathrm{T}_{3}$ was detected by RIA (Total $\mathrm{T}_{4}$ or Total $\mathrm{T}_{3}$ Mab-ICN Pharmaceuticals, Costa Mesa, CA, USA). Minimum assay detection value was $25 \mathrm{ng} / \mathrm{dl}$ for $\mathrm{T}_{3}, 1 \mu \mathrm{g} / \mathrm{dl}$ for $\mathrm{T}_{4}$, and within-assay variation was less than $4.5 \%$ for $T_{3}$ and less than $3 \cdot 5 \%$ for $\mathrm{T}_{4}$ in all assays. Samples of the same experiment were run within the same assay.

\section{Statistical analyses}

Data are reported as mean \pm S.E.M. Serum TSH was analyzed employing Kruskal-Wallis test followed by Dunn's multiple comparison test or Mann-Whitney test, in experiments with two experimental groups. One-way ANOVA followed by Dunnett's multiple comparison test was employed for an assessment of the significance of in vitro TSH. $\mathrm{T}_{4}$ and $\mathrm{T}_{3}$ data were analyzed by ANOVA or unpaired $t$-test, according to the number of experimental groups (Zar 1996). Null hypothesis was discarded when $P<0 \cdot 05$.

\section{Results}

Acute effect of anandamide on thyrotropin and thyroid hormones secretion on euthyroid, hypothyroid, and hyperthyroid rats

In euthyroid rats (Fig. 1A), serum TSH was decreased by $\sim 42 \%$ in animals that had received, $2 \mathrm{~h}$ earlier, a single
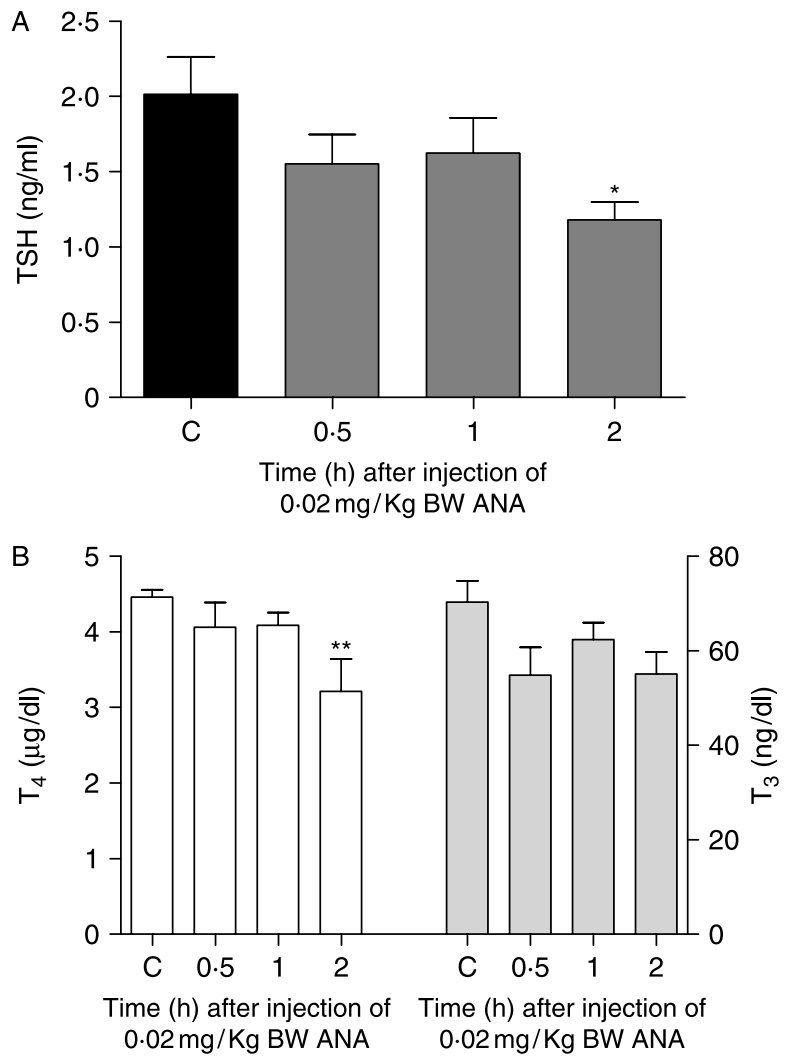

Figure 1 Serum (A) TSH, (B) $T_{4}$ and $T_{3}$ concentrations in euthyroid rats after i.p. administration of $0.02 \mathrm{mg} / \mathrm{kg}$ BW anandamide (ANA) or vehicle $(C$, control). Determinations were performed at $0 \cdot 5,1$, and $2 \mathrm{~h}$ after the injection. $n=10-12$ animals per group. ${ }^{*} P<0 \cdot 05$ ${ }^{* *} P<0 \cdot 01$ versus control group. Data are presented as mean \pm S.E.M.

systemic injection of $0 \cdot 02 \mathrm{mg} / \mathrm{kg} \mathrm{BW}$ anandamide $(P<0 \cdot 05)$. At the same time interval, serum $\mathrm{T}_{4}$ showed a $39 \%$ reduction $(P<0.01$; Fig. 1B). At earlier time-points $(0.5$ and $1 \mathrm{~h})$, anandamide had no significant effect on serum TSH or serum $\mathrm{T}_{4}$. Serum $\mathrm{T}_{3}$ was statistically similar among all groups (Fig. 1B). However, a ten-time higher anandamide dose $(0 \cdot 2 \mathrm{mg} / \mathrm{kg})$ had no effect on serum TSH, $\mathrm{T}_{4}$, and $\mathrm{T}_{3}$ (Fig. 2).

In hypothyroid animals, $2 \mathrm{~h}$ after the low-dose-anandamide administration, a reduction of $\sim 35 \%$ in serum TSH was
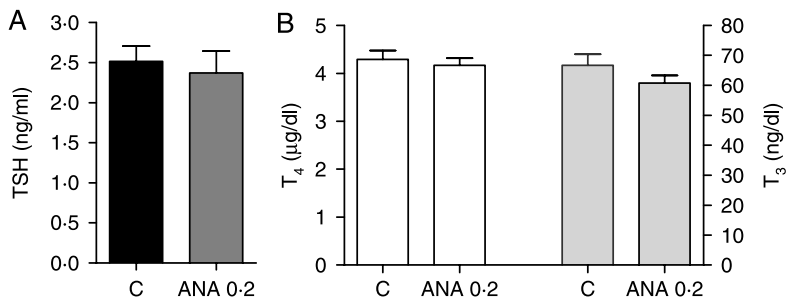

Figure 2 Serum (A) $\mathrm{TSH}$, (B) $\mathrm{T}_{4}$ and $\mathrm{T}_{3}$ concentrations in euthyroid rats after i.p. administration of $0.2 \mathrm{mg} / \mathrm{kg}$ BW anandamide (ANA $0 \cdot 2)$ or vehicle $(C$, control). Determinations were performed at $2 \mathrm{~h}$ after the injection. $n=9-10$ animals per group. Data are presented as mean \pm S.E.M. 
observed $(P<0 \cdot 01$; Fig. 3A), but there was no change in serum thyroid hormones concentrations (Fig. 3B).

In hyperthyroid animals, serum TSH did not change in response to low dose anandamide administration. As expected, hyperthyroid rats presented reduced serum TSH $(0 \cdot 4 \pm 0 \cdot 27 \mathrm{ng} / \mathrm{ml}$ for vehicle; $n=4$ and $0 \cdot 3 \pm 0 \cdot 1 \mathrm{ng} / \mathrm{ml}$ for anandamide treated; $n=3$ ) and some of the animals (five of vehicle- and four of anandamide-treated groups) had serum TSH lower than the detection limit of assay $(0 \cdot 18 \mathrm{ng} / \mathrm{ml})$. Also, serum $\mathrm{T}_{4}$ and $\mathrm{T}_{3}$ remained unchanged by anandamide treatment $\left(\mathrm{T}_{4}: 7 \cdot 85 \pm 0 \cdot 4 \mu \mathrm{g} / \mathrm{dl}\right.$ for vehicle, and 8.08 \pm $0 \cdot 4 \mu \mathrm{g} / \mathrm{dl}$ for anandamide injected; $\mathrm{T}_{3}: 132 \cdot 9 \pm 9 \cdot 1$ for vehicle and $154 \cdot 8 \pm 9 \cdot 9 \mathrm{ng} / \mathrm{dl}$ for anandamide treatment).

Acute effect of CB1 receptor antagonist AM251 on thyrotropin secretion of euthyroid rats

As depicted in Fig. 4A, a single injection of AM251, injected $1.5 \mathrm{~h}$ before killing, induced a dose increase in serum TSH, of $1.7(P<0.05)$ or 4.3 times $(P<0 \cdot 001)$ in animals receiving $0 \cdot 17$ or $1.7 \mathrm{mg} / \mathrm{kg} \mathrm{BW}$ AM251 respectively (Fig. $4 \mathrm{~B}$ ). However, no statistically significant effects were observed regarding serum $\mathrm{T}_{4}$ and $\mathrm{T}_{3}$.

Acute effect of CB1 receptor antagonist AM251 and anandamide on thyrotropin secretion of euthyroid rats

Figure 5 shows that the inhibitory effect of $0.02 \mathrm{mg} / \mathrm{kg} \mathrm{BW}$ anandamide and the stimulatory effect of $0.17 \mathrm{mg} / \mathrm{kg} \mathrm{BW}$ AM251 were abolished in rats receiving AM251 $30 \mathrm{~min}$ before the injection of anandamide. The latter group presented serum TSH statistically similar to control group. All animals were killed $2 \mathrm{~h}$ after anandamide injection.

\section{Effect of intracerebroventricular injection of anandamide in euthyroid rats}

Serum TSH was evaluated before and at 30, 60, and $120 \mathrm{~min}$ after injection into the third ventricle of 20 or $200 \mathrm{ng}$ anandamide. Figure 6 shows the variation of serum TSH in relation to basal levels (before injection). At $30 \mathrm{~min}$,
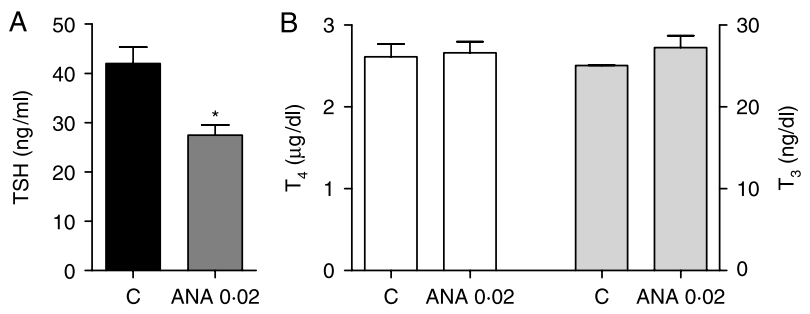

Figure 3 Serum (A) $\mathrm{TSH}_{1}$ (B) $\mathrm{T}_{4}$ and $\mathrm{T}_{3}$ concentrations in hypothyroid rats after i.p. administration of $0.02 \mathrm{mg} / \mathrm{kg} \mathrm{BW}$ anandamide (ANA $0 \cdot 02$ ) or vehicle (C, control). Determinations were performed at $2 \mathrm{~h}$ after the injection. $n=8-9$ animals per group. $* P<0 \cdot 01$ versus control group. Data are presented as mean \pm S.E.M.
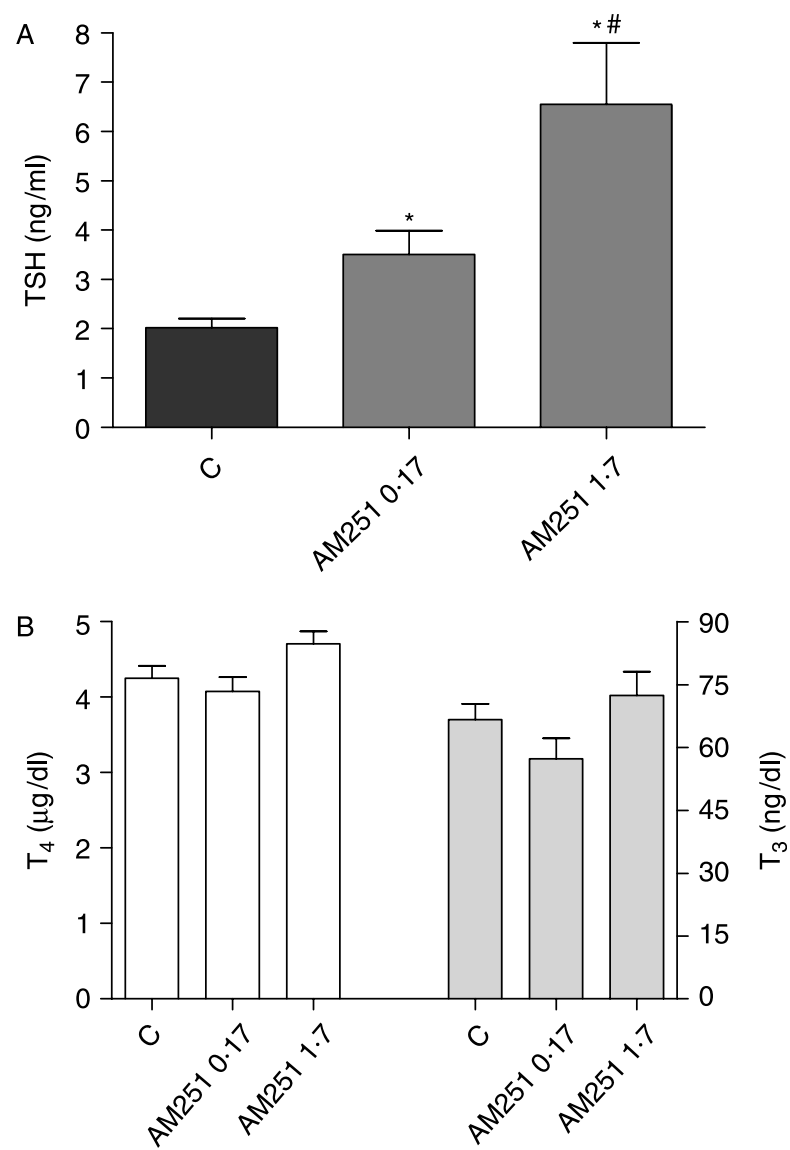

Figure 4 Serum (A) $\mathrm{TSH}$, (B) $\mathrm{T}_{4}$ and $\mathrm{T}_{3}$ concentrations in euthyroid rats after i.p. administration of the selective $\mathrm{CB} 1$ receptor antagonist, AM251 in the dose of 0.17 or $1.7 \mathrm{mg} / \mathrm{kg} \mathrm{BW}$ or vehicle (C, control). Determinations were performed at $1.5 \mathrm{~h}$ after the injection. $n=10-11$ animals per group. $P<0.05$ versus ${ }^{*}$ control group or versus ${ }^{\#}$ AM251 $0 \cdot 17$. Data are presented as mean \pm S.E.M.

anandamide injection, at both doses, caused no significant change in TSH secretion. At $60 \mathrm{~min}$, anandamide at $20 \mathrm{ng}$ induced a significant reduction in TSH secretion $(P<0 \cdot 05)$. The same trend was observed with $200 \mathrm{ng}$ anandamide; however, the variation in serum TSH was not statistically significant. One hour later (at $120 \mathrm{~min}$ after microinjection), no significant effect was observed, although only the group treated with $20 \mathrm{ng}$ anandamide still had a trend to reduce TSH secretion.

Effect of anandamide and AM251 in pituitary explants of euthyroid rats

The presence of anandamide in incubation media of hemipituitary glands showed a dose-related effect on TSH released to the medium. At $10^{-11} \mathrm{M}$, release of TSH was increased $(1.6$ times, $P<0 \cdot 05)$; however, at $10^{-7} \mathrm{M}$, there was a significant reduction (66\%), while the intermediary dose $\left(10^{-9} \mathrm{M}\right)$ induced no significant change in secretion 

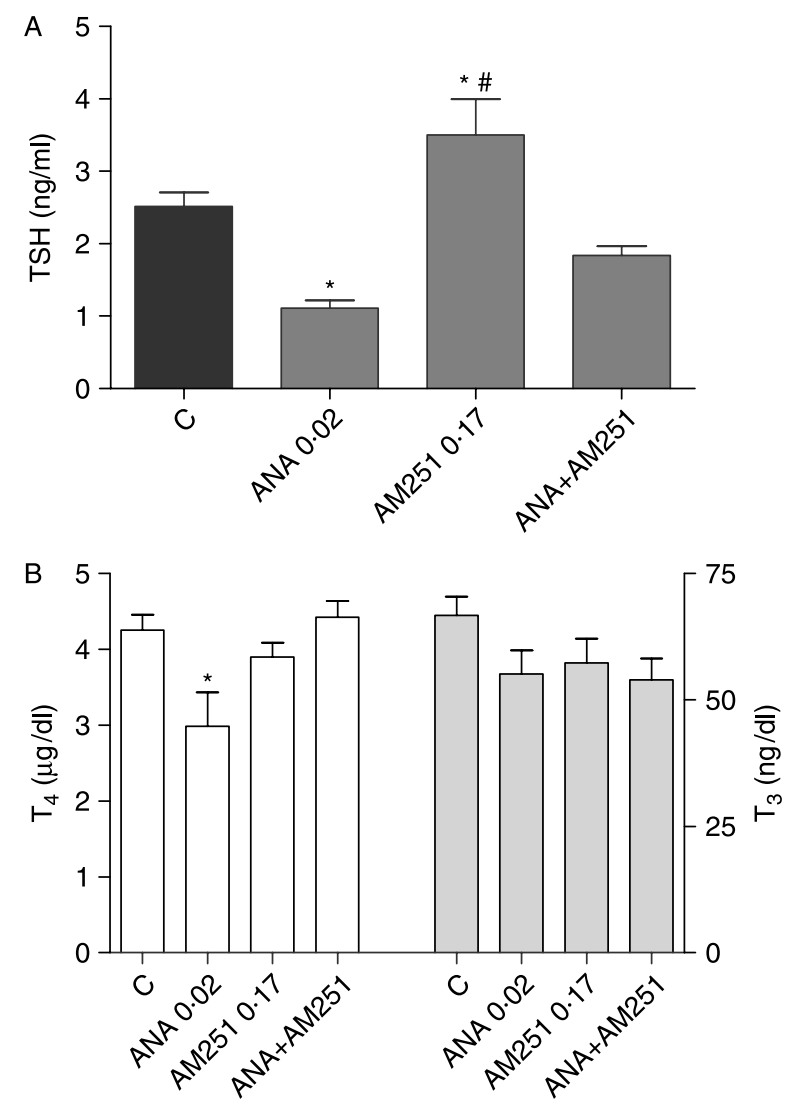

Figure 5 Serum (A) TSH, (B) $\mathrm{T}_{4}$ and $\mathrm{T}_{3}$ concentrations in euthyroid rats after i.p. administration of $0.02 \mathrm{mg} / \mathrm{kg} B W$ anandamide (ANA $0 \cdot 02$ ) or $0.17 \mathrm{mg} / \mathrm{kg}$ BW AM251, a selective CB1 receptor antagonist (AM251 0.17), or $0.17 \mathrm{mg} / \mathrm{kg}$ BW AM251 followed by $0.02 \mathrm{mg} / \mathrm{kg}$ BW anandamide injection $30 \mathrm{~min}$ later (ANA + AM251) or vehicle $(C$, control). Determinations were performed at $2 \mathrm{~h}$ after ANA injection. $n=9-11$ animals per group. $P<0 \cdot 05$ versus *control group versus *ANA 0.02. Data are presented as mean \pm s.E.M.
(Fig. 7A). In the second experiment, we observed that the inhibitory effect of $10^{-7} \mathrm{M}$ anandamide in TSH release was blocked by the CB1 receptor antagonist AM251 at $10^{-7} \mathrm{M}$ $\left(P<0 \cdot 05\right.$; Fig. 7B). The incubation with $10^{-7} \mathrm{M}$ AM251 alone showed a non-statistically significant trend to increase TSH release in comparison with control and a significant increase in relation to anandamide-treated group $(P<0 \cdot 05)$, which showed a $30 \%$ decrease in relation to control $(P<0 \cdot 05$; Fig. 7B).

\section{Discussion}

The present study demonstrated that the endocannabinoid, anandamide, injected systemically or centrally into rats exhibited the ability to inhibit TSH secretion, while acute administration of the inverse agonist AM251 increases the hormone secretion.

The inhibitory effect of anandamide on TSH secretion occurred $2 \mathrm{~h}$ after systemic injection and was accompanied by concomitant reduction in serum $T_{4}$. These data suggest that anandamide acts at the pituitary and/or hypothalamus in order to inhibit TSH secretion, since increased TSH would be expected if the only site of action was the thyroid. An earlier study showed that the phytocannabinoid $\Delta$ 9-THC was able to reduce serum TSH from $15 \mathrm{~min}$ to $3 \mathrm{~h}$ after a single i.p. injection, followed by a decrease in serum $\mathrm{T}_{3}$ and $\mathrm{T}_{4}$ at 3 and $6 \mathrm{~h}$ respectively (Hillard et al. 1984). However, in our study, the reduction in serum TSH and $\mathrm{T}_{4}$ was concomitant and, considering the long half-life of serum $\mathrm{T}_{4}$, unless TSH bioactivity was reduced at a much earlier time, it is likely that anandamide was also acting at the thyroid gland. In support to a direct action in the thyroid, there was the previous report by Porcella et al. (2002), showing that $4 \mathrm{~h}$ after the injection of cannabinoid receptor agonist WIN 55212-2, serum thyroid hormones were reduced without changes in serum TSH. This effect of the

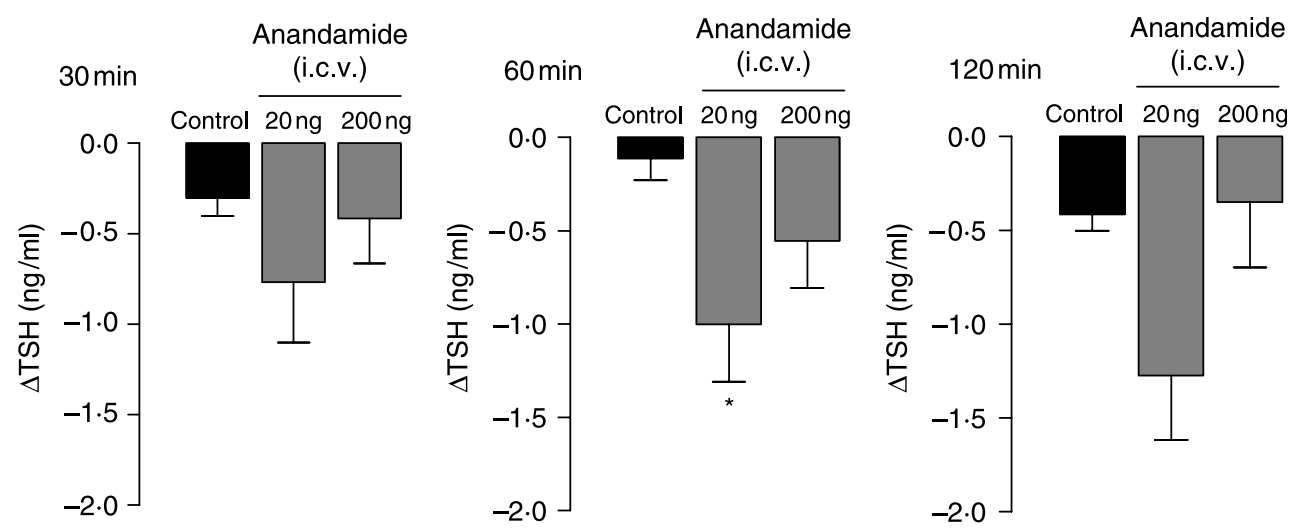

Figure 6 Serum TSH variation $(\Delta \mathrm{TSH})$ in relation to zero time, before microinjection, and at 30, 60, or $120 \mathrm{~min}$ after microinjection of 20 or $200 \mathrm{ng}$ anandamide into the third cerebral ventricle of euthyroid rats. Data represent mean \pm S.E.M., $n=6-8$ animals per group. ${ }^{*} P<0 \cdot 05$ versus control group. 

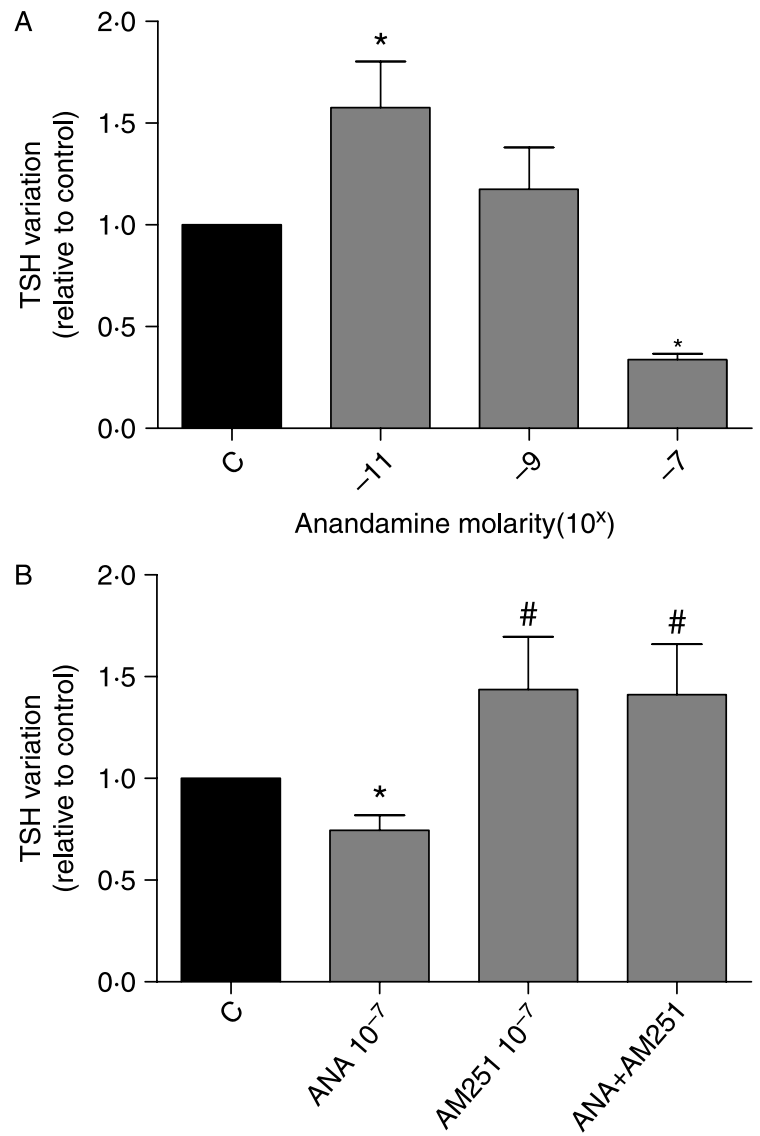

Figure 7 (A) TSH release from isolated rat hemi-anterior pituitary glands incubated in the absence $(\mathrm{C}$, control) or presence of anandamide at $10^{-11}, 10^{-9}$, or $10^{-7} \mathrm{M}$ for $2 \mathrm{~h}$. (B) TSH release from isolated rat hemi-anterior pituitary glands incubated in the absence $\left(\mathrm{C}\right.$, control), presence of $10^{-7} \mathrm{M}$ anandamide (ANA $10^{-7}$ ), $10^{-7} \mathrm{M} \mathrm{AM} 251$ (AM251 $10^{-7}$ ), or both drugs at the same molarity (ANA + AM251) for $2 \mathrm{~h}$. Data represent mean \pm S.E.M. and correspond to two experiments and expressed in relation to basal secretion, which was set to $1 . n=9-14$, hemi-pituitaries/group. $P<0 \cdot 05$ versus *all groups and versus ${ }^{*} \mathrm{ANA} 10^{-7}$.

agonist was abolished by pre-treatment with specific CB1 antagonist SR 141716A. However, it is not clear which subtype of cannabinoid receptor mediates the effect of WIN 55212-2, on thyroid, since, so far, only CB1 was found in the thyroid (Porcella et al. 2002), and WIN 55212-2 is a CB2 preferring agonist.

Further evidence of the central action of anandamide was obtained by the demonstration of the inhibitory anandamide effect of on TSH secretion, without changes in serum thyroid hormones, in rats treated with methimazol, a drug that inhibits thyroid hormone biosynthesis. In addition, the fact that anandamide preserves its ability to reduce serum TSH in hypothyroid state highlights the potency of endocannabinoid effect on TSH regulation, since lack of thyroid hormones is a major determinant of high serum TSH (Weintraub et al.
2001). However, apparently, anandamide was not able to further decrease the already suppressed TSH serum concentrations of hyperthyroid rats.

The involvement of CB1 receptors in the control of TSH release is suggested by the acute rise in serum TSH induced by AM251 and by the fact that AM251 pre-treatment prevented anandamide effect. AM251 stimulatory effect on TSH release may be interpreted as that of anandamide, which acts preferentially by $\mathrm{CB} 1$ receptors, having a tonic inhibitory effect that is blocked by the CB1 receptor antagonist. Another likely explanation would be that AM251, acting as an inverse agonist, reduces the CB1 receptor signaling transduction pathway (Pertwee 2005). AM251, injected into the third cerebral ventricle, had been reported to change LH and PRL secretions in the opposite direction to anandamide effects (Scorticati et al. 2003, 2004). Serum thyroid hormones did not change in response to the rise in $\mathrm{TSH}$ induced by AM251, which may be related to the short time observed after the drug administration $(1.5 \mathrm{~h})$ or to the biological potency of the amount of TSH secreted. In a previous study (Porcella et al. 2002), systemic injection of CB1 receptor antagonist SR141716A did not modify serum $\mathrm{TSH}, \mathrm{T}_{3}$, or $\mathrm{T}_{4}$. However, hormonal evaluation was performed $4 \mathrm{~h}$ after injection, while we used an earlier time in the current study. Therefore, it remains to be elucidated whether these different reports are related to time-course or to particularities attributed to each drug.

CB1 receptors have been demonstrated, albeit in low density, in hypothalamic nuclei (Fernandez-Ruiz et al. 1997, Scorticati et al. 2004) and also CB1-like immunoreactivity was found in rat and human anterior pituitaries (FernandezRuiz et al. 1997, Pagotto et al. 2001, Scorticati et al. 2004). Therefore, the in vivo effect of anandamide on TSH release may result from a direct action at pituitary and/or hypothalamus. The possibility of a direct hypothalamic action is reinforced by the inhibitory effect we observed within $60 \mathrm{~min}$ after the i.c.v. administration of $20 \mathrm{ng}$ anandamide. Wenger et al. (1997) had used a systemic treatment regimen identical to that employed in the present study and demonstrated that anandamide increased POMC release in concomitance with proto-oncogene protein c-fos (FOS) activation in paraventricular nucleus (PVN) hypothalamic neurons, peaking at $90 \mathrm{~min}$ after anandamide injection. Therefore, the time-course of our results is in accordance with a postulated action at hypothalamic site. In addition, earlier studies had shown that the phytocannabinoid $\Delta$ 9-THC was not able to acutely affect serum TSH in animals with electrolytic lesions in medial mammillary nuclei of the hypothalamus (Lomax et al. 1970). Regarding systemic administration of AM251, a hypothalamic site of action is also possible, since previous studies have shown that following i.v. injection of [123 I]AM251 in mice, the peak whole-brain uptake of about $1 \%$ of the administered activity occurred at about $1 \mathrm{~h}$ and declined thereafter (Gatley et al. 1996). In addition, there are reports of centrally mediated effects induced by systemic acute administration of AM251, 
employed in the same dose range of our higher dose, such as a decrease in food ingestion behavior (Chambers et al. 2004) and inhibition of cocaine-induced reinstatement of rewardseeking behavior (Xi et al. 2006).

The precise mechanism by which endogenous cannabinoid may modify TSH release cannot be elucidated by the present study. Considering the short half-life of anandamide and the relative long latency for the anandamide central effect on serum TSH, it is possible that this endocannabinoid did not act directly on TRH neurons, but likely that other mechanisms are involved (de Miguel et al. 1998, Scorticati et al. 2003). Scorticati et al. (2003) reported that dopamine concentration in medial basal hypothalamus and anterior pituitary was increased $90 \mathrm{~min}$ after a single intracerebroventricular injection of anandamide, which concomitantly induced inhibition of PRL release (Scorticati et al. 2003). Since dopamine is an inhibitor of PRL and TSH (Weintraub et al. 2001), a mechanism by which anandamide may inhibit PRL and also TSH release is via increasing dopamine input.

However, endocannabinoids may also modulate TSH secretion by a direct pituitary action. We were able to demonstrate the ability of anandamide at $10^{-7} \mathrm{M}$ to reduce TSH release, an effect at least in part mediated by cannabinoid receptor 1, since it was blocked by AM251. However, anandamide at lower molarity $\left(10^{-11} \mathrm{M}\right)$ provoked an increase in TSH secretion to medium, and therefore the pituitary action of endogenous cannabinoid may vary depending on the concentration present in the gland.

Interestingly, a ten-time higher dose of anandamide, injected systemically or centrally, was not able to affect the thyrotropic axis. There are many reports showing lower biological efficacy of endogenous substances administered at higher dose than lower doses, including anandamide (Ortiga-Carvalho et al. 2002, Fernandez-Solari et al. 2004, Scorticati et al. 2004, Oliveira et al. 2006).

Thyroid hormones and endocannabinoids participate in energy homeostasis in opposite directions; while thyroid hormones are major stimulants of the basal metabolic rate and energy expenditure, endocannabinoids are important stimulators of food ingestion and energy conservation. During starvation, thyrotropic axis activity is reduced (Weintraub et al. 2001), while endocannabinoid levels increase (Matias \& Di Marzo 2007). Therefore, it seems feasible to the existence of a physiologically relevant negative regulation of thyrotropic axis by endocannabinoids. In addition, since CB1 receptor antagonists are currently being introduced in therapeutics (Di Marzo et al. 2004), it will be important to investigate the consequences to pituitary-thyroid axis of chronic administration of CB1-receptors antagonists.

In conclusion, anandamide, an endogenous cannabinoid, has the ability to acutely inhibit TSH release in eu- and hypothyroid rats, acting at the hypothalamus-pituitary axis. Since the cannabinoid receptor antagonist, AM251, increased TSH release in vivo and blocked the effect of anandamide, it is suggested that endocannabinoid system may play a role as a negative regulator of TSH secretion in vivo.

\section{Declaration of interest}

The authors declare that there is no conflict of interest that would prejudice the impartiality of this scientific work.

\section{Funding}

This work was supported by Conselho Nacional de Pesquisa e Desenvolvimento and Fundação Carlos Chagas Filho de Amparo a Pesquisa do Estado do Rio de Janeiro.

\section{References}

Antunes-Rodrigues J \& McCann SM 1970 Water, sodium chloride, and food intake induced by injections of cholinergic and adrenergic drugs into third ventricle of the rat brain. Proceedings of the Society for Experimental Biology and Medicine 133 1464-1470.

Chambers AP, Sharkey KA \& Koopmans HS 2004 Cannabinoid (CB)1 receptor antagonist, AM 251, causes a sustained reduction of daily food intake in the rat. Physiology and Behavior 82 863-869.

Chard T 1987 An introduction to radioimmunoassay and related techniques. In Laboratory Techniques in Biochemistry and Molecular Biology, pp 1-74. Eds RH Burdon \& H van Kiniooenberg. Amsterdam: Elsevier Science.

Devane WA, Dysarz FA, Johnson MR, Melvin LS \& Howlett AC 1988 Determination and characterization of a cannabinoid receptor in rat-brain. Molecular Pharmacology 34 605-613.

Fernandez-Ruiz J, Munoz RM, Romero J, Villanua MA, Makriyannis A \& Ramos JA 1997 Time course of the effects of different cannabimimetics on prolactin and gonadotrophin secretion: evidence for the presence of CB1 receptors in hypothalamic structures and their involvement in the effects of cannabimimetics. Biochemical Pharmacology 53 1919-1927.

Fernandez-Solari J, Scorticati C, Mohn C, De Laurentiis A, Billi S, Franchi A, McCann SM \& Rettori V 2004 Alcohol inhibits luteinizing hormonereleasing hormone release by activating the endocannabinoid system. PNAS $1013264-3268$.

Foster-Schubert KE \& Cummings DE 2006 Emerging therapeutic strategies for obesity. Endocrine Reviews 27 779-793.

Gatley SJ, Gifford AN, Volkow ND, Lan RX \& Makriyannis A 1996 I-123labeled AM251: a radioiodinated ligand which binds in vivo to mouse brain cannabinoid CB1 receptors. European Journal of Pharmacology 307 331-338.

Hillard CJ, Farber NE, Hagen TC \& Bloom AS 1984 The effects of delta-9tetrahydrocannabinol on serum thyrotropin levels in the rat. Pharmacology, Biochemistry, and Behavior 20 547-550.

Klein TW 2005 Cannabinoid-based drugs as anti-inflammatory therapeutics. Nature Reviews. Immunology 5 400-411.

Lomax P, Kokka N \& George R 1970 Thyroid activity following intracerebral injection of morphine in rat. Neuroendocrinology 6 146-152.

Di Marzo V \& Fontana A 1995 Anandamide, an endogenous cannabinomimetic eicosanoid: killing two birds with one stone. Prostaglandins, Leukotrienes, and Essential Fatty Acids 53 1-11.

Di Marzo V, Bifulco M \& De Petrocellis L 2004 The endocannabinoid system and its therapeutic exploitation. Nature Reviews. Drug Discovery 3 771-784.

Matias I \& Di Marzo V 2007 Endocannabinoids and the control of energy balance. Trends in Endocrinology and Metabolism 18 27-37.

Matsuda LA, Lolait SJ, Brownstein MJ, Young AC \& Bonner TI 1990 Structure of a cannabinoid receptor and functional expression of the cloned cDNA. Nature 346 561-564.

McLaughlin PJ, Winston KM, Limebeer CL, Parker LA, Makriyannis A \& Salamone JD 2005 The cannabinoid CB1 antagonist AM251 produces food avoidance and behaviors associated with nausea but does not impair feeding efficiency in rats. Psychopharmacology 180 286-293.

de Miguel R, Romero J, Munoz R, Garcia-Gil L, Gonzalez S, Villanua MA, Makriyannis A, Ramos JA \& Fernandez-Ruiz JJ 1998 Effects of cannabinoids on prolactin and gonadotrophin secretion: involvement of changes in hypothalamic gamma-aminobutyric acid (GABA) inputs. Biochemical Pharmacology 56 1331-1338. 
Munro S, Thomas KL \& Abushaar M 1993 Molecular characterization of a peripheral receptor for cannabinoids. Nature 365 61-65.

Oliveira KJ, Paula GS, Costa-e-Sousa RH, Souza LL, Moraes DC, Curty FH \& Pazos-Moura CC 2006 Peptide YY (PYY)3-36 modulates thyrotropin secretion in rats. Journal of Endocrinology 191 459-463.

Ortiga-Carvalho TM, Polak J, McCann S \& Pazos-Moura CC 1996 Effect of thyroid hormones on pituitary neuromedin $\mathrm{B}$ and possible interaction between thyroid hormones and neuromedin B on thyrotropin secretion. Regulatory Peptides 67 47-53.

Ortiga-Carvalho TM, Oliveira KJ, Soares BA \& Pazos-Moura CC 2002 The role of leptin in the regulation of TSH secretion in the fed state: in vivo and in vitro studies. Journal of Endocrinology 174 121-125.

Pagotto U, Marsicano G, Fezza F, Theodoropoulou M, Grubler Y, Stalla J, Arzberger T, Milone A, Losa M, Di Marzo V et al. 2001 Normal human pituitary gland and pituitary adenomas express cannabinoid receptor type 1 and synthesize endogenous cannabinoids: first evidence for a direct role of cannabinoids on hormone modulation at the human pituitary level. Journal of Clinical Endocrinology and Metabolism 86 2687-2696.

Pazos-Moura CC, Moura EG, Rettori V, Polak J \& McCann S 1996 Role of neuromedin $\mathrm{B}$ in the in vitro thyrotropin release in response to thyrotropinreleasing hormone (TRH) from anterior pituitaries of eu-, hypo- and hyperthyroid rats. Proceedings of the Society for Experimental Biology and Medicine 211 353-358.

Pertwee RG 2005 Inverse agonism and neutral antagonism at cannabinoid CBI receptors. Life Sciences 76 1307-1324.

Porcella A, Marchese G, Casu MA, Rocchitta A, Lai ML, Gessa GL \& Pani L 2002 Evidence for functional CB1 cannabinoid receptor expressed in the rat thyroid. European Journal of Endocrinology 147 255-261.

Rettori V, Milenkovic L, Fahim AM, Polak J, Bloom SR \& McCann SM 1989 Role of neuromedin $\mathrm{B}$ in the control of the release of thyrotropin in the rat. PNAS 86 4789-4792.

Rettori V, Pazos-Moura CC, Moura EG, Polak J \& McCann SM 1992 Physiological role of neuromedin B in control release of thyrotropin in hypothyroid and hyperthyroid rats. PNAS 89 3035-3039.

Scorticati C, Mohn C, De Laurentiis A, Vissio P, Solari JF, Seilicovich A, McCann SM \& Rettori V 2003 The effect of anandamide on prolactin secretion is modulated by estrogen. PNAS 100 2134-2139.
Scorticati C, Fernandez-Solari J, De Laurentiis A, Mohn C, Prestifilippo JP, Lasaga M, Seilicovich A, Billi S, Franchi A, McCann SM et al. 2004 The inhibitory effect of anandamide on luteinizing hormone-releasing hormone secretion is reversed by estrogen. PNAS 101 11891-11896.

Tsou K, Brown S, Sanudo-Pena MC, Mackie K \& Walker JM 1998 Immunohistochemical distribution of cannabinoid CB1 receptors in the rat central nervous system. Neuroscience 83 393-411.

Weidenfeld J, Feldman S \& Mechoulam R 1994 Effect of the brain constituent anandamide, a cannabinoid receptor agonist, on the hypothalamo-pitutaryadrenal axis in the rat. Neuroendocrinology 59 110-112.

Weintraub BD, Kazlauskaite R, Grossmann M \& Szkudlinski MW 2001 Thyroid-stimulating hormone and regulation of the thyroid axis. In Endocrinology, edn 4, pp 1345-1360. Eds L DeGroot \& JL Jameson. Philadelphia: Saunders Company.

Wenger T, Toth BE \& Martin BR 1995 Effects of anandamide (endogen cannabinoid) on anterior-pituitary hormone-secretion in adult ovariectomized rats. Life Sciences 56 2057-2063.

Wenger T, Jamali KA, Juanéda C, Léonardelli J \& Tramu G 1997 Arachidonyl ethanolamide (anandamide) activates the parvocellular part of hypothalamic paraventricular nucleus. Biochemical and Biophysical Research Communications 237 724-728.

Wenger T, Fernandez-Ruiz JJ \& Ramos JA 1999 Immunocytochemical demonstration of CB1 cannabinoid receptors in the anterior lobe of the pituitary gland. Journal of Neuroendocrinology 11 873-878.

Xi ZX, Gilbert JG, Peng XQ, Pak AC, Li X \& Gardner EL 2006 Cannabinoid $\mathrm{CB}$ receptor antagonist AM251 inhibits cocaine-primed relapse in rats: role of glutamateinthe nucleus accumbens. Journal of Neuroscience 26 8531-8536.

Zar J 1996 Data transformations. In Biostatistical Analysis, 3rd edn, pp 277-279. London: Prentice Hall International.

\section{Received in final form 20 August 2008 \\ Accepted 27 August 2008 \\ Made available online as an Accepted Preprint 28 August 2008}

